\title{
スリットプレートダンパーを有する半剛接合部の実験 EXPERIMENTAL STUDY ON THE SEMI-RIGID BEAM-TO-COLUMN CONNECTIONS WITH SLIT PLATE DAMPERS
}

\author{
呉 相 勲*1, 山田 哲*2, 秋山宏*3, 大竹章夫*4, 福田浩司*5 \\ Sang-Hoon OH, Satoshi YAMADA, Hiroshi AKIYAMA, \\ Fumio OTAKE: and Koji FUKUDA
}

\begin{abstract}
The flexible-stiff mixed structure, where the main frame is used as a flexible element and the earthquake input energy is mainly absorbed by energy absorption element, is suggested to enable an effective earthquake resistant design. In order to achieve such flexible-stiff mixed structure, a connection with a slit-type steel plate damper installed at each ends of wide-flange section beam, as an energy absorption element, was proposed through this research. A series of experiment was carried out to evaluate their structural performance and behavior. The main parameter of experiment was the aspect ratio of the struts in slit plates. Experimental results indicates that most of the energy was absorbed by plastic deformation of slit plate dampers. Additionally, the behavior of such type of connection can be expressed into the sum of the behavior of non-diaphragm connection, where only the web of beam is welded to the column, with that of the slit plate damper.
\end{abstract}

Keywords : hysteretic damper, connection, energy absorption capacity, flexible-stiff mixed structure 履歷型ダンパー、接合部、エネルギー吸収能力、柔剛混合構造

1. 序

極限地震下で構造物の耐震性能を確保するためには、構造物に地 震による入力エ゙ネルギーを上回るエネルギー吸収能力を付与しなく てはならない。従来の耐震設計では、重力を支える主架構に地震に よる入力エネルギーの吸収も期待していたが、重力を支持する主架 構と地震による入力エネルギーを吸収するエネルギー吸収要素を分 離することで、より合理的な耐震設計が可能となる。強震下におい ても主架構を弾性範囲に留めるには、主架構の剛性を小さくし、剛 性の大きなエネルギー吸収要素を組み込むことになる。これが、重 力を支持する主架構を柔要素、エネルギー吸収要素を剛要素とする 柔剛混合構造 "である。

柔剛混合構造の可能性の一つとして、エネルギー吸収要素を忘力 の大きくなる梁端部に設け、梁降伏型のような全体降伏型のメカニ ズムを形成し、効率の良いエネルギー分散型骨組を実現することが 考えられる。接合部を半剛接合とすることで、弾性変形量の大きい
主架構が実現する。半剛接合部を用いた柔らかい骨組(柔要素)に、 剛性の高い弾塑性履歴型ダンパーをエネルギー吸収要素(剛要素)と してて組み込むことで、骨組の初期剛性を確保すると同時に、地震に よる入カエネルギーをダンパーで吸収することができる。

筆者らはこれまでに、剛性が小さく弾性変形量の大きい柔要素と して、角形鋼管柱一H形梁接合部のダイアフラ.ムを省略した無補強 半剛接接合部の実験を行い、その力学的特性を明らかにした ${ }^{2 !}$ 。ま た、エネルギー吸収要素である剛要素として、スリットプレートダ ンパーの繰り返し載荷実験を行い、その復元力特性とエネルギー吸 収能力を明らかにした”。

本研究では、ダイアフラムを省略した無補強半剛接接合部"を拡 張し、梁フランジから柱への応力伝達をスリットプレート型ダンパ 一を介して行うようにした柔剛混合形式接合部について、静的繰り 返し載荷実験を行い、その力学的特性を評価するとともに、履歷挙 動を予測する力学モデルを構築する。
*1 浦項産業科学研究院 博士 (工学)

*2 東京工業大学建築物理研究センタ一 助教授・博士 (工学)

*3 日本大学総合科学研究所 教授

東京大学 名誉教授・工博

*4 住友金属 工博

*5. 住友金属 博士 (工学)
Research Institute of Industrial Science \& Tech., Dr. Eng.

Assoc. Prof., Structural Engineering Research Center, Tokyo Institute of Technology, Dr. Eng.

Prof., Nihon Univ., Prof. Emeritus, Univ. of Tokyo, Dr. Eng.

Sumitomo Metal Industries, Dr. Eng. Sumitomo Metal Industries, Dr. Eng. 


\section{2. 試験体}

試験体は柱を角形鋼管、梁を $\mathrm{H}$ 型鋼とする十字型の部分架構で ある。概形を図-1に示す。接合部はダイアフラムを省略した半剛接 合部 ${ }^{2)}$ とっているが、梁フランジから柱への応力伝達をスリット プレートを介して行うようになっている。すなわち、梁ウェブにつ いては柱に完全溶け込み溶接されているが、梁フランジについてば、 材端を $30 \mathrm{~mm}$ 切り落として絶縁したうえで、柱との間にスリットプレ 一トを装着している。スリットプレートは、一方の縁で梁フランジ と同一平面上で完全溶け込み溶接され、もう一方の縁で柱に応力を 伝達するための繸板に溶接されている。

本実験で用いた試験体は全部で5体であり、スリットプレートの ストラットの幅とスリットプレートの柱への取り付け方が主要なパ ラメーターとなっている。スリットプレートの取り付け方について は、CDタイプとIDタイプがあり、CDタイプの試験体では、スリット プレートを柱に接続するための綐板の外面を柱ウェブの中心線に合
わせているが、IDタイプ試験体では綐板の外面を柱ウェブの内側に 合わせている。これは、CDタイプの試験体での綐板の柱への溶接位 置が、塑性加工による影響で材質が劣化している角部にあたり、溶 接には最も不利な場所であることの影響を検討するために設定した パラメーターである。

試験体の一覧を表-1に示す。表中 $B_{s}$ はスリットプレートのストラ ットの幅、 $H_{s}$ はストラットの平行部の長さ、 $r_{s}$ はストラットの $\mathrm{R}$ 部 の半径、 $t_{s}$ はスリットプレートの板厚、 $n_{s}$ はスリットプレート 1 枚 あたりのストラットの本数である。各試験体のスリットプレートの 長さはいずれも $24 \mathrm{~cm}$ であり、スリットプレート 1 枚あたりのストラ ットの本数は、CD10試験体では8本、CD20、ID20では6本、CD28、ID 28試験体では5本となっている。使用鋼材であるが、柱についてはS TKR400材を、梁及びスリットプレートについてはSM490材を用いた。 使用鋼材の JIS-1A 号試験片による素材試験結果を表-2に示す。
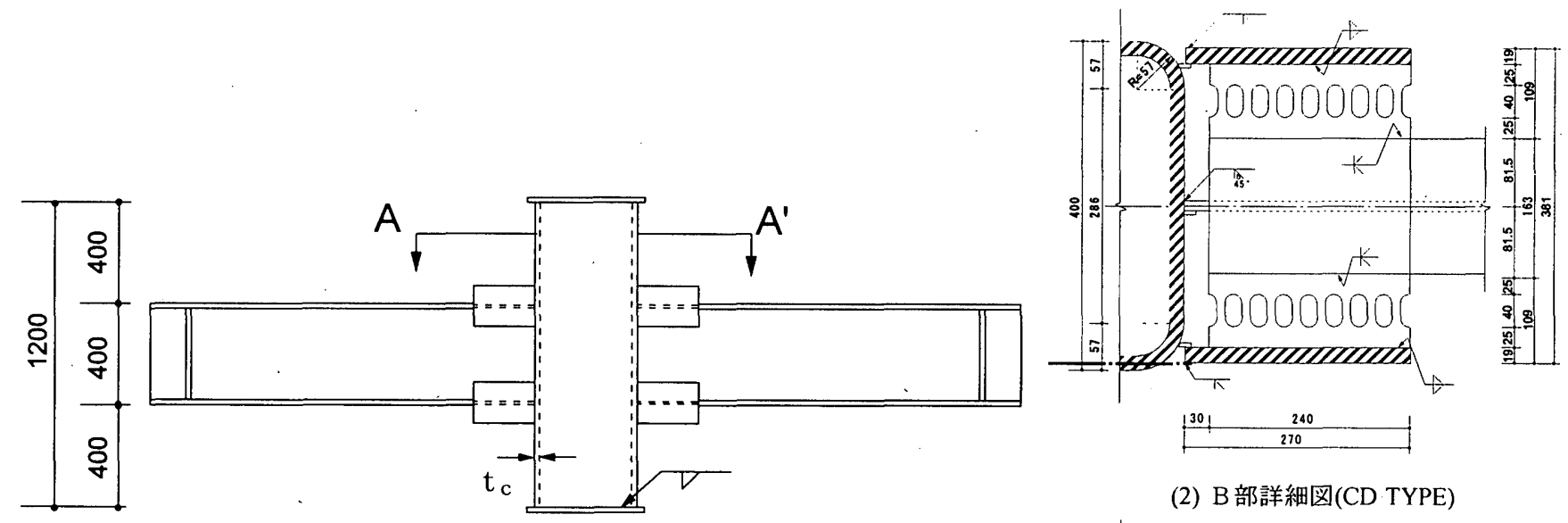

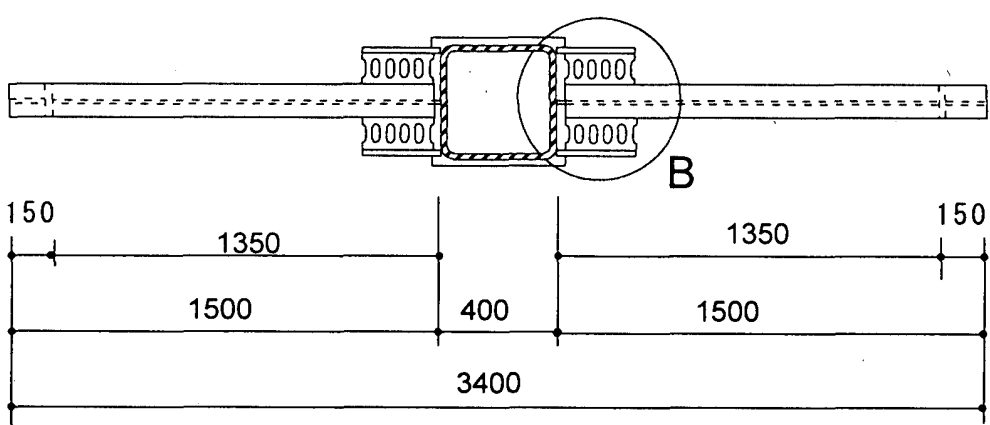

(1) 全体図 (立面および A-A'断面)

(2) B 部詳細図(CD TYPE)
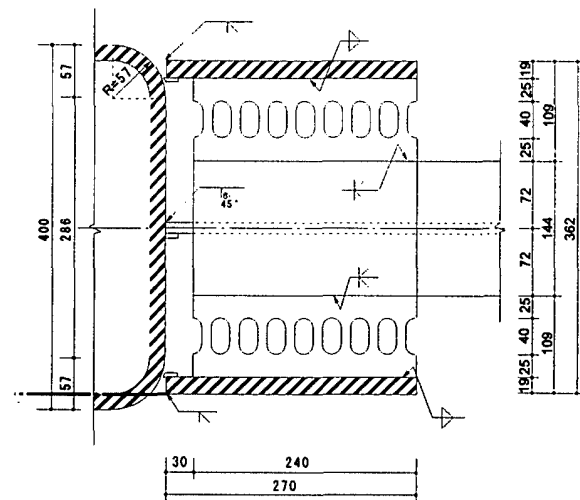

(3) B 部詳細図(ID TYPE)

図-1 試験体形状

表-1 試験体一覧

\begin{tabular}{|c|c|c|c|c|c|c|c|}
\hline \multirow[b]{2}{*}{ 試験体 } & \multirow[b]{2}{*}{ 柱断面 } & \multirow[b]{2}{*}{ 梁断面 } & \multicolumn{5}{|c|}{ ダンパー形状 } \\
\hline & & & $\begin{array}{r}B s \\
(\mathrm{~mm})\end{array}$ & $\begin{array}{r}H s \\
(\mathrm{~mm})\end{array}$ & $\begin{array}{r}r s \\
(\mathrm{~mm})\end{array}$ & $\begin{array}{r}t s \\
(\mathrm{~mm})\end{array}$ & $\begin{array}{c}n s \\
\text { (本) }\end{array}$ \\
\hline CD10 & \multirow{5}{*}{$\square-400 \times 400 \times 19$} & \multirow{3}{*}{$H-400 \times 163 \times 12 \times 19$} & 10 & \multirow{5}{*}{20} & \multirow{5}{*}{10} & \multirow{5}{*}{16} & 8 \\
\hline $\mathrm{CD} 20$ & & & 20 & & & & 6 \\
\hline CD28 & & & 28 & & & & 5 \\
\hline 1020 & & \multirow[t]{2}{*}{$H-400 \times 144 \times 12 \times 19$} & 20 & & & & 6 \\
\hline 1028 & & & 28 & & & & 5 \\
\hline
\end{tabular}

表-2 素材試験結果

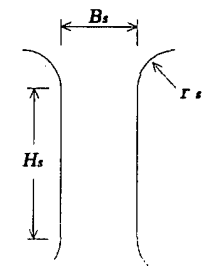

\begin{tabular}{|l|c|c|r|r|r|}
\hline & 錭種 & 使用部位 & $\begin{array}{c}\text { 降伏耐カ } \\
(\mathrm{MPa})\end{array}$ & $\begin{array}{c}\text { 破断柇カ } \\
(\mathrm{MPa})\end{array}$ & $\begin{array}{c}\text { 破断伸び } \\
(\%)\end{array}$ \\
\hline PL19 & STKR400 & 柱(平板部) & 357 & 400 & 25.4 \\
\hline PL19 & SM490 & 梁(フランジ) & 311 & 487 & 25.9 \\
\hline PL12 & SM490 & 梁(ウェブ) & 335 & 523 & 25.7 \\
\hline PL16 & SM490 & ダンパー & 346 & 621 & 19.2 \\
\hline
\end{tabular}

図-2 ストラット 形状 


\section{3. 実験方法}

実験は3点曲げ方式で行った。セットアップを図-3に示す。載荷 には油圧式2000ton試験機を用い、載荷点上部の球座を固定した平 押しの条件で柱部に荷重を加えた。変形の計測には図-3に示す位置 に取り付けた変位計を用い、柱部の鉛直変位を計測した。載荷パタ ーンは、初期載荷時において概ね塑性率が 2 程度となった变位を変 位振幅の増分とする、漸増変位振幅繰り返し載荷とした。

\section{4. 実験結果}

\section{1 実験経過}

図-4に各試験体の荷重一変形関係曲線を示す。縦軸は梁端部に作 用するせん断力であり、横軸は图-3に示した変位計(1)、(2)で計測し た接合部位置におげる鉛直変位である。図中の印はスリットプレ 一トに発生した亀裂の進展にようて、耐力の低下が始まる点を示し

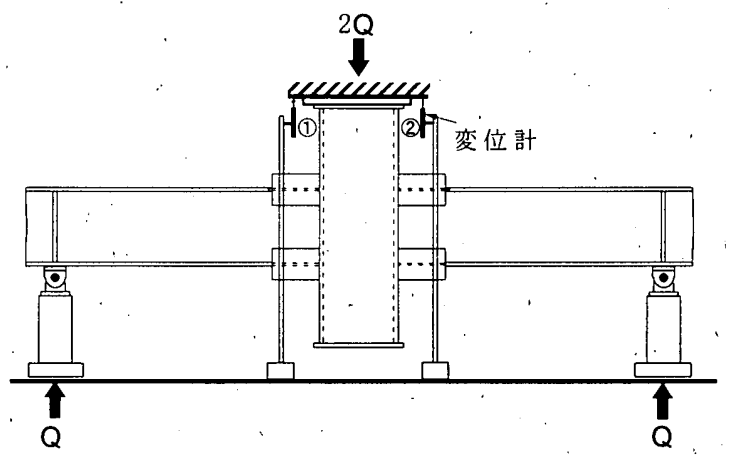

図-3 実験セットアップ

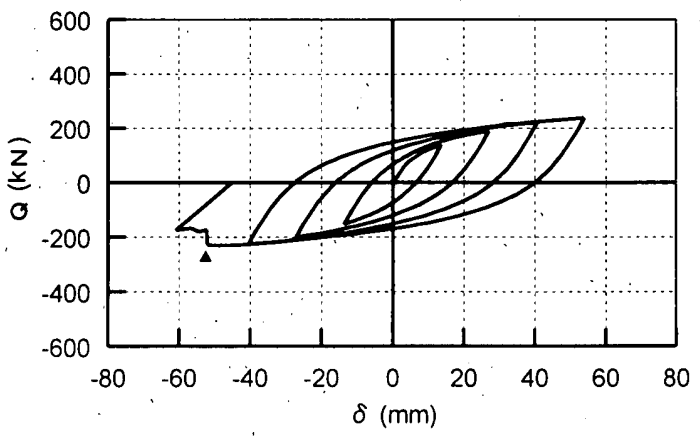

(1) $\mathrm{CD} 10$

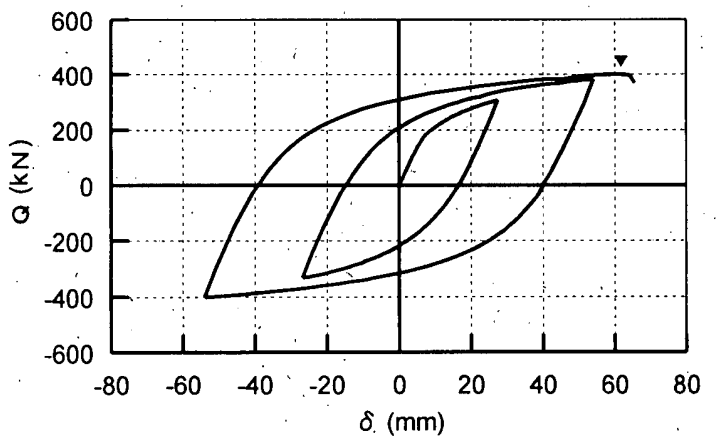

(2) $\mathrm{CD} 20$
ている。同じスリットプレートを装着したCD20、ID20、CD28、ID28 の各試験体からは、ほぼ同じ履歴特性が得られた。

すべての試験体において、最大耐力に達した後耐力の低下が始ま ると直ちにズリットプレートが破断し、急激な耐力の低下が見られ た。そしてある程度耐力が低下した後、柱フランジの面外抵抗によ る耐力の上昇が見られた。これは、ダンパーが破断した後にも完全 溶け込み溶接されたウェブと柱の接合箇所が健在であり、ウェブを 介して十分な曲げ忍力の伝達がなされたことによる。

また、実験終了時の柱フラシジ角部の溶接部は $\mathrm{CD}$ タイプ、ID タイプ試験体共に健全であった。また、柱フランジと梁ウェブの溶 接部では、溶接部近傍の柱フランジ母材に延性亀裂が生じていたが、 スリットプレートが破断した後の変形の進行によって生じたもので あり、亀裂の進展による耐力の低下は見られなかった。

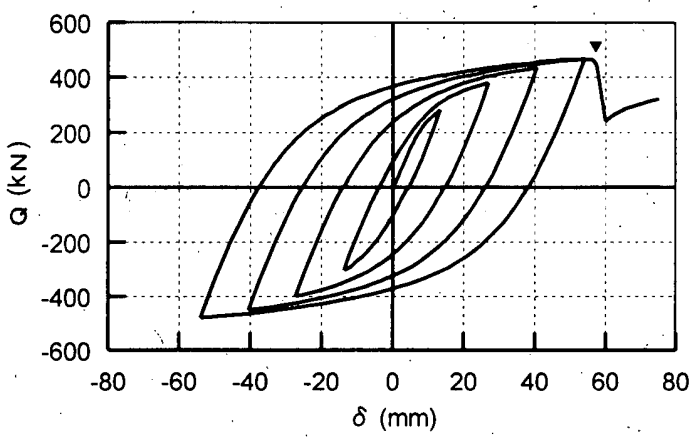

(3) $\mathrm{CD} 28$

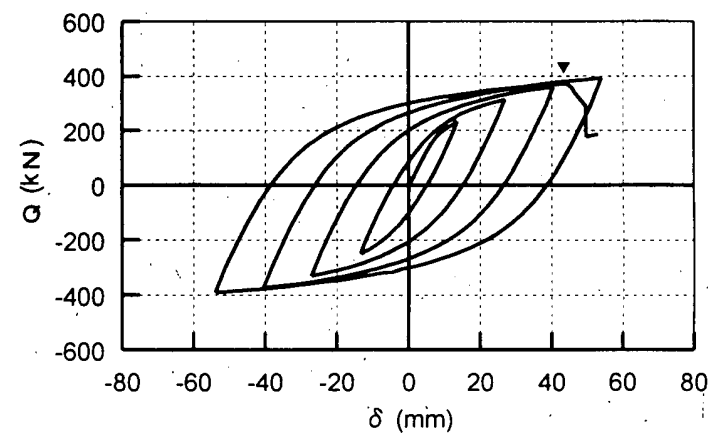

(4) ID20

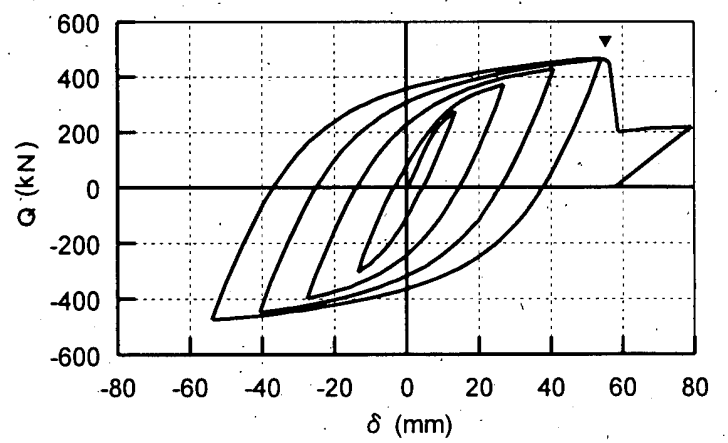

(5) ID28

図-4 荷重-変形関係 


\section{2 初期剛性}

荷重-変形関保から求めた試験体の初期剛性(接線剛性)を、同一の 断面を有する梁についてダンパーをつけない通常の柱梁接合部(剛 接合)としたときの剛性と比較し図-5に示す。今回の実験で用いた 試験体では、 $\mathrm{CD} 10$ 試験体で通常の柱梁接合部に対して $1 / 3$ 程度、 他の 4 体の試験体で $1 / 2$ 程度の剛性となっている。

\section{3 履歴吸収エネルギー}

スリットプレートの破断によって決まる最大耐力点までに試験体 が吸収した履歷吸収エネルギーW $W_{p}$ を表一 3 に示す。履歴吸収エネル ギーの大部分はスリットプレートの塑性変形によってなされたもの である。表中、W $W_{p i}$ は同位置の断面を有する梁を剛接合としたとき の単位塑性仕事であり、梁断面の全塑性耐力 $Q_{p}$ と全塑性耐力に対 忘した先端の弾性変形 $\delta_{p} \delta_{p}^{*}$ の積である。また、 $\overline{\eta^{*}}$ は試験体の履歴吸 収エネルギーを、剛接合とした梁の累積塑性変形倍率に置換した值 であり、 $W_{p}$ を $W_{p l}$ で除して求めた。各試験体とも、スリットプレ一 トが破断するまでの変形量は大差なかったが、耐力の違いがエネル ギー吸収能力の違いとして現れた。梁の全塑性耐力 $Q_{p}$ は、フラン ジ幅の広い $\mathrm{CD}$ シリーズで362 $(k N)$ 、フランジ幅の狭い ID シリーズ で330(kN)であり、もっとも酎力の小さかった CD10 試験体では、

最大耐力でも $Q_{p} の 2 / 3$ 程度であったが、他の 4 体の試験体の最大 耐力はっ $Q_{\rho}$ を回るものであった。剛接部材に置換した累積塑性変 形倍率司でみると、CD10 試験体ではやや小さめの值となったが、 安定した梁降伏型のメカニズムを形成しうることを考えれば、部材 のエネルギー吸収能力に基づく耐震設計を行うには十分な值である といえる。

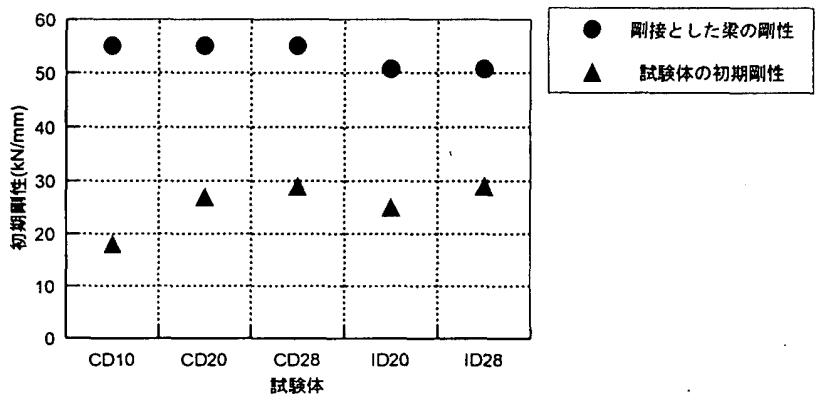

図-5 試験体の初期剛性

表-3 履歴吸収エネルギー

\begin{tabular}{l|r|r|r}
\hline & $\begin{array}{c}W_{p} \\
(k N \cdot m)\end{array}$ & $\begin{array}{c}W_{p 1}{ }^{*} \\
(k N \cdot m)\end{array}$ & \multicolumn{1}{c}{$\overline{\eta^{*}}$} \\
\hline 試験体 & 52.9 & 2.38 & 22.2 \\
\hline CD10 & 84.5 & 2.38 & 35.5 \\
\hline CD20 & 134.2 & 2.38 & 56.4 \\
\hline CD28 & 108.6 & 2.15 & 50.4 \\
\hline ID20 & 130.5 & 2.15 & 60.6 \\
\hline ID28 & \multicolumn{3}{|c}{} \\
\hline
\end{tabular}

\section{5. 復元力特性の検討}

\section{1 而荷機構と变形状態}

実験から得られた繰り返し荷重下における試験体の荷重-变形関 倸を、スリットプレート・無補強接合部・梁の各変形要素の荷重変形関倸に明確に分解して評価することはできないが、変形要素そ れぞれ復元力特性のモデルに基づき試験体の荷重-変形関係を予測 し、実験から得られた荷重-変形関倸と比較検討寸る。

試験体を構成する変形要素であるが、試験体の片スパンを外力条 件・変形状態に基づき、图一6に示すように要素分割する。分割され た変形要素は、(1)スリットプレートの面内変形、(2)スリットプレー トの面外変形、(3)無補強接合部の変形、(4)スリットプレートが取り 付く部分の梁の曲げ変形、スリットプレートが取り付く部分の外側 の梁の曲げ変形の 5 つである。

梁の先端に作用するせん断力の一部は梁ウェブを介して柱に伝達 されるが、残りはスリットプレートから縦板を介して柱に伝達され る。せん断力の一部がスリットプレートに作用することで、図-6中 に示した面外変形が生じる。このスリットプレートの面外変形は： スリットプレートが接合されている縦板と梁の相対変位と対応した ものとなる。スリットプレートが接合される区間での梁の曲げ変形 量は小さく：縌板との相対変位は無補強接合部の変形による梁材端 部での回転角 $\theta$ と対応したものになる。従って、無補強接合部とス リットプレートの面外变形举動とそれに伴う抵抗は、図-6に示寸よ うに、無補強接合部の剛性を $c K$ スリットプレートの面外剛性を $s_{2} 2 K$ とする並列バネとしてモデル化する。また、せん断力によって生じ る曲げモーメントにようてスリットプレートには面内変形が生じ る。梁フランジの中心間距離を $h_{c} 、$ スリットプレートの変形量を $\Delta$ とすると、スリットプレートの面内変形によって生じる梁材端部の 回転角は $\theta=2 \Delta / h_{\mathrm{c}}$ であり、接合部における変形の適合条件から ${ }_{c} \theta={ }_{s} \theta$ となるので、スリットプレートの面内変形挙動と抵抗も、図一 7に示すように、スリットプレートの面内剛性を $s^{\prime} K$ とする並列バネ としてモデル化する。そして梁については、スリットプレートが取 り付く部分とその外側に分割することで、それぞれの荷重条件に対 态したバネにモデル化することができるので、材端部分の並列バネ から連なる直列バネとして、図-7に示すようにモデル化する。

\section{2 スリットプレートの履歴挙動}

繰り返し荷重を受ける試験体のスリットプレートは面内と面外に 強制変形を受け、実際の履歴挙動は両者の影響を反映したものとな るが、面内変形による塑性化が十分早期に起こることから、面内変 形に対する履歴挙動には面外変形に対する履歴挙動の影響は出ない ものと仮定する。繰り返し曲げを受けるスリットプレートの荷重変形関係(面内挙動)は、図-8に示すように、一方向荷重下における 荷重-変形関保と概ね一致する骨格曲線 ${ }^{4)}$ とバウシンガー部 ${ }^{3)}$ そして 弾性除荷部に分解できる ${ }^{3}$ 。このうち骨格曲線については、要素実 験より tri-linear 型にモデル化されている ${ }^{3)}$ 。文献 3)のモデルを、本 研究で扱う上下フランジの左右合計 4 カ所にスリットプレートを配 した半剛接合部に適用し、スリットプレートの履歴挙動を予測する。 接合部における荷重-変形関保を、梁の先端に作用するせん断力 $Q$ と梁の先端の変位 $\delta$ 関係で表し、文献 3 )のモデルを適用すると、 

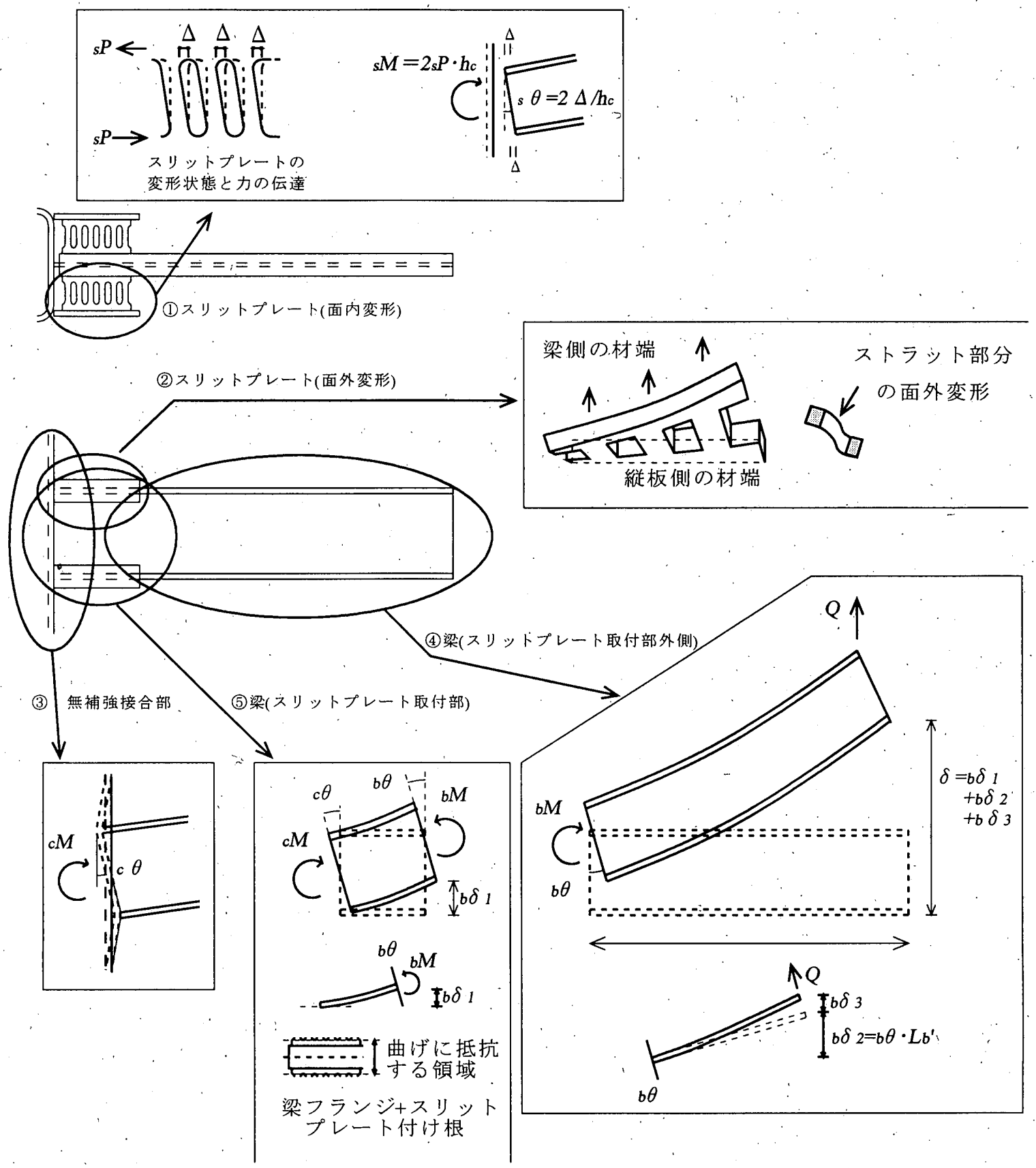

図-6 試験体の変形状態と要素分割

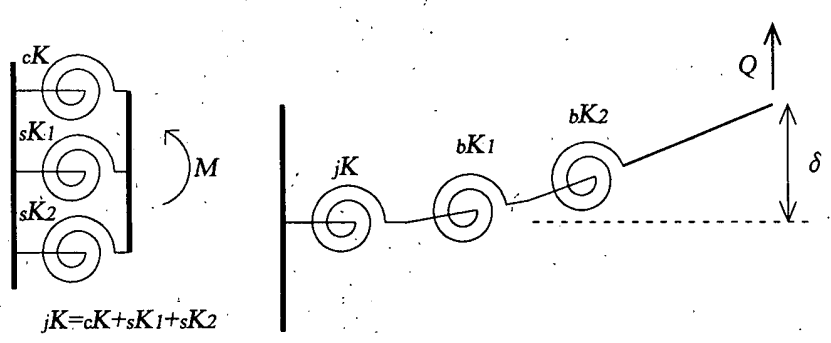

図-7 而荷機構

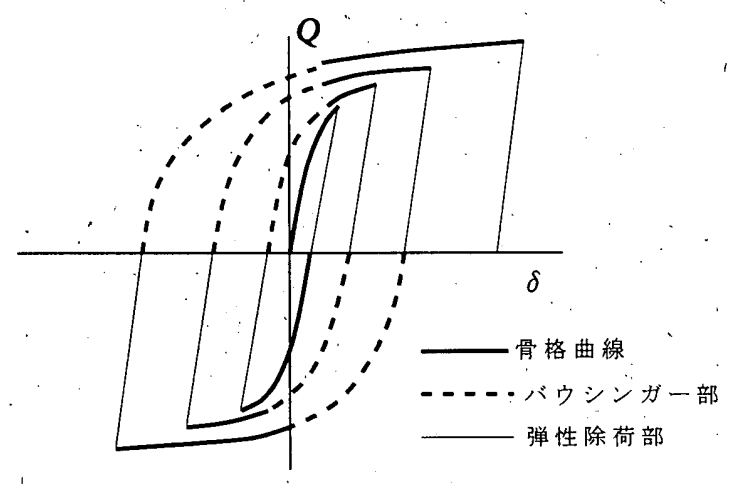

図-8 荷重-変形関係の分解(スリットプレート·梁) 
1 次剛性 $s K_{1}$ 、降伏耐力s $Q_{1} 、 2$ 次剛性 $s K_{2} 、 2$ 次剛性から 3 次剛性へと 移行する耐力 $Q_{2} 、 3$ 次剛性 $s_{3}$ は以下のように表される。ここで、 スリットプレートに作用する外力は応力勾配の影響で材長方向に変 化するが、平均值であるスリットプレート中心位置に作用するカで 代表した。

$$
{ }_{s} K_{l}=\frac{\dot{n}_{s} \cdot E \cdot t_{s} \cdot B_{s} \cdot h_{c}}{1.5\left(2 r_{s}+H_{s}\right) \cdot\left[\left(\frac{H_{s}^{\prime}}{B_{s}}\right)^{2}+2.6\right] \cdot L_{b} \cdot\left(L_{b}-l_{s}\right)^{2}}
$$

スリットプレートの降伏耐カが曲げで決まる場合

$$
\begin{aligned}
& { }_{s} Q_{I}=\frac{n_{s} \cdot \sigma_{u s} \cdot B_{s}{ }^{2} \cdot t_{s} \cdot h_{c}}{H \cdot\left(L_{b}-l_{s}\right)} \\
& { }_{s} K_{2}=I / 25_{s} K \\
& { }_{s} Q_{2}=\frac{n_{s} \cdot \sigma_{u s} \cdot B_{s}{ }^{2} \cdot t_{s} \cdot h_{c}}{H \cdot\left(L_{b}-l_{s}\right)} \\
& { }_{s} K_{3}=I / / 25_{s} K_{I}
\end{aligned}
$$

スリットプレートの降伏耐力がせん断で決まる場合

$$
\begin{aligned}
& { }_{s} Q_{1}=\frac{4 \cdot n_{s} \cdot \sigma_{y s} \cdot B_{s} \cdot t_{s} \cdot h_{c}}{3 \sqrt{3} \cdot\left(L_{b}-l_{s}\right)} \\
& { }_{s} K_{3}=1 / 75_{s} K_{l} \\
& { }_{s} Q_{2}=\frac{4 \cdot n_{s} \cdot \sigma_{u s} \cdot B_{s} \cdot t_{s} \cdot h_{c}}{3 \sqrt{3} \cdot\left(L_{b}-l_{s}\right)} . \\
& { }_{s} K_{3}=1 / 225_{s} K_{l}
\end{aligned}
$$

ここで、E:弾性係数

$$
\begin{aligned}
& H_{s}^{\prime}=H_{s}+\frac{2 r_{s}^{2}}{\left(H_{s}+2 r_{s}\right)} \\
& \iota_{b} \text { : 柱フェイスより反力点までの距離 }:=1.350 \mathrm{~mm} \text {; } \\
& l_{s} \text { :柱フェイスよりダンパー中心までの距離 } \\
& (=150 \mathrm{~mm}) \\
& \sigma_{y s:} \text { スリットプレート材の降伏耐力 }
\end{aligned}
$$

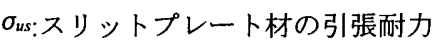

また、バウシンガー部については、文献 5)の履歷モデルを用いた。

一方、面外変形については以下のようにモデル化した。面外方向 への変形量は材長方向で変化するが、平均的な挙動となる材長方向 の中心位置での挙動で代表し、材長方向に均等に変形が生じるもの として弹性剛性を求めた。さらに、面内変形で塑性化を開始した時 点で面外方向にも降伏するものと仮定し、骨格曲線については 2 次 剛性が 0 となる bi-linear 型のモデルを、バウシンガー部については 文献 5)の履歴モデルを適用した。

\section{3 無補強接合部の履歴挙動}

ダイアフラムを省略した無補強接合部については、既報 2)で形 状・荷重条件を主たるパラメーターとした 16 体の試験体の実験結 果から、梁の変形までを含んだ片スパン分の履歴挙動を bi-linear 型 の復元力特性にモデル化した。この履歴モデルを基に、柱フランジ の面外変形分を抽出し、無補強接合部の履歴モデルを Bi-linear 型 にモデル化したは。履歴モデルを梁の先端に作用するせん断力 $Q$ と 梁の先端の変位 $\delta$ の関係で表したときの降伏耐力 ${ }^{2} Q_{y} 、 1$ 次剛性 ${ }^{\prime} K_{1} 、 2$ 次剛性 ${ }^{c} K_{2}$ は式(10) (12)で与えられる。

$$
\begin{gathered}
{ }_{c} Q_{y}=1.38_{c} \sigma_{y} t_{c}^{2}\left(2 \sqrt{\frac{b_{c}}{b_{c}-B_{b}}}+\frac{t_{r}}{b_{c}-B_{b}}\right) h_{d} / L_{b} \\
{ }_{c} K_{1}=25 E I^{*}\left(B_{b} / b_{c}\right)^{4}\left(h_{c} / B_{b}\right)^{2}\left(b_{c} / t_{c}\right) / L_{b}{ }^{2} \\
{ }_{c} K_{2}=0.09 E I^{*}\left(B_{b} / b_{c}\right)^{3.6}\left(h_{d} B_{b}\right)^{2.2}\left(b d t_{c}\right)^{2} / L_{b}{ }^{2} \\
こ こ て ゙ 、 \sigma_{y: \text { 柱フランジ材の降伏点 }} \\
t_{c} \text { 柱フランジの板厚 } \\
b_{c} \text { :柱フランジの板厚中心間距離 } \\
B_{b} \text { :梁フランジ幅 } \\
t_{r} \text { :梁フランジの溶接寸法 } \\
I^{*}=t_{c}^{3} / 12
\end{gathered}
$$

本研究で用いた試験体では梁フランジは柱とは絶縁され梁ウェブ のみ接合されている。復元力特性のモデルを適用するにあたり、梁 フランジ幅 $B_{b}$ としてウェブの板厚を代入し、梁フランジの溶接寸法 $t_{r}$ として 0 を、梁フランジ中心間距離 $h_{c}$ としてウェブの成を代入し た。

\section{4 梁の履歴挙動}

梁はスリットプレートが取り付く部分とその外側に分割される が、外側については片持梁として扱うことができる。スリットプレ 一トが取り付く部分についても、ウェブのみ接合された無補強接合 部の剛性は十分に小さく柱の抵抗モーメント ${ }^{2} M$ は先端側のモーメ ント ${ }_{b} M$ に比べて十分に小さいことから 0 であると見なし、途中の モーメントは連続的に変化すると仮定することで、柱側を自由端と する片持ち梁と見なした。なお、この部分の断面については、図一6 中にも示したように、梁のフランジに接合されたスリットプレート の付け根の部分も曲げに抵抗するものとして強度と剛性の算定を行 った。

繰り返し曲げを受ける梁の荷重-変形関係は、图-8に示したよう に、一方向荷重下における荷重-変形関係と概ね一致する骨格曲線 ${ }^{4}$ とバウシンガー部"そして弾性除荷部に分解でき、骨格曲線につい ては、 2 次剛性が 1 次剛性の 3\%となる bi-linear 型のモデル"を用い、 バウシンガー部にう゚いては文献 5)の履歷モデルを用いた。

\section{5 予測結果と実験結果の比較}

図-7の力学モデルに $5.2 \sim 5.4$ で説明した各変形要素の履歴挙動 を適用し、各試験体の荷重-変形関係の予測を行った。予測結果を 実験結果と比較し、図-9に示す。図中実線は実験結果を、破線は予 測結果を表す。スリットプレートが曲げ降伏する CD10 試験体では 予測結果は高めの剛性を与えているが、スリットプレートがせん断 降伏する他の 4 体の試験体では、載荷初期よりスリットプレート型 ダンパーの破断によって決まる最大耐力までの履歴挙動において、 予測結果と実験結果は良い対応を示している。今回用いたスリット プレートがせん断降伏する試験体については、荷重-変形関倸の予 測計算結果は妥当であると言える。 


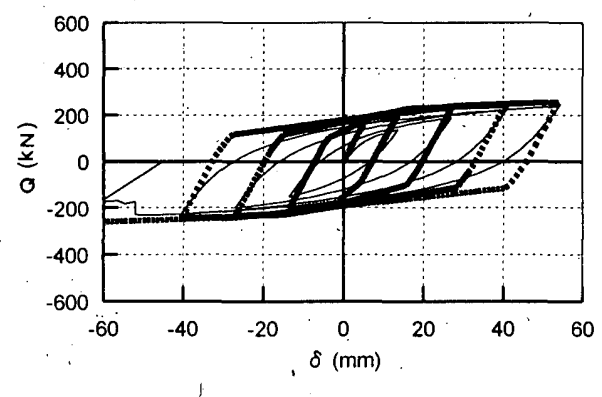

(1) $\mathrm{CD} 10$

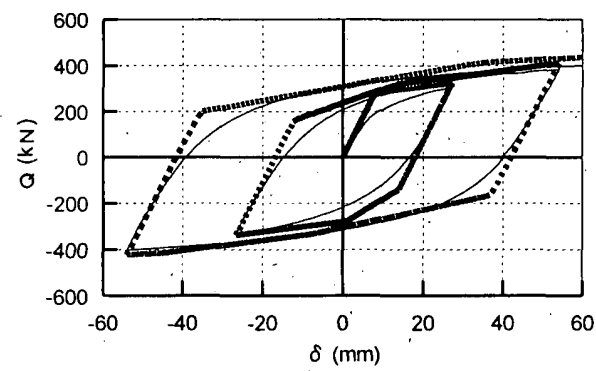

(2) $\mathrm{CD} 20$

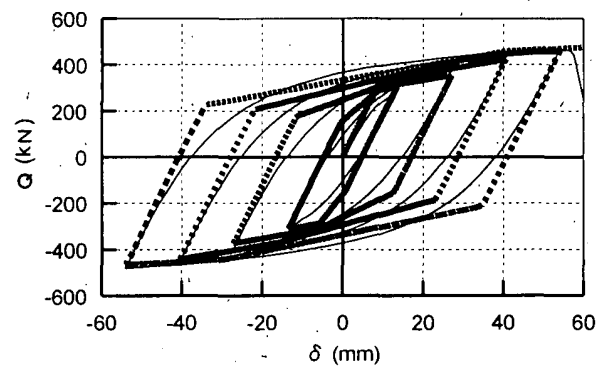

(3) $\mathrm{CD} 28$

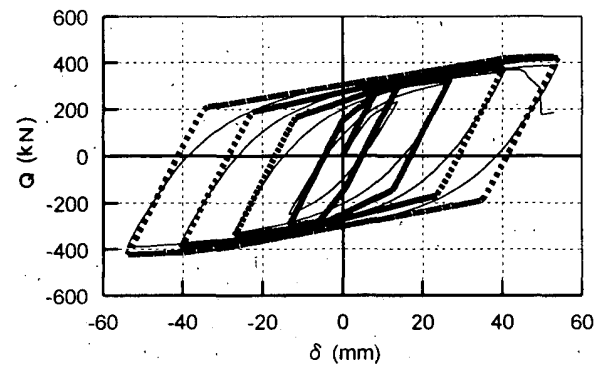

(4) ID20

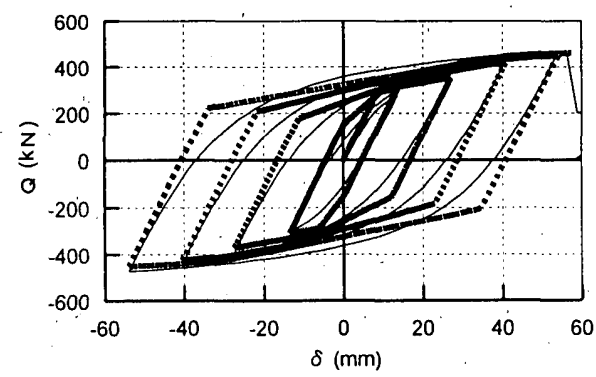

(5) ID28

図-9 荷重-変形関係の予測結果と実験結果の比較

\section{6. 結論}

梁降伏型のような全体降伏型のメカニズムを形成し、効率の良い エネルギー分散型柔剛混合骨組を実現するための、ダイアフラムを 省略した無補強半剛接接合部 ${ }^{2)}$ を拡張し、梁フランジから柱への応 力伝達をスリットプレート型ダンパーを介して行うようにした柔剛 混合形式接合部について、繰り返し載荷実験を行つた。実験結果に 基づき、以下の知見を得た。

(1)柔剛混合形式接合部の履歴挙動は、安定した紡鍾型の形状を示 し、スリットプレートの破断によって決まる最大耐力まで安定した エネルギー吸収能力を発揮する。

(2)今回用いた試験体では、初期剛性が接合部を剛接とした場合の 1/2 から $1 / 3$ 程度の半剛接合部となっていた。スリットプレートの 形状と接合部剛性の関係については、現時点では限られた実験結果 しか得られていないが、エネルギー吸収能力を有する半剛接合部と しての可能性を示す結果が得られた。

(3)接合部ならびに梁を外力条件・変形状態に基づき変形要素に分 割し、それぞれの変形要素の履歴挙動をモデル化した、柔剛混合構 造接合部を有する梁部材の荷重-変形関係の予測計算方法を示した。 予測計算結果は、スリットプレートが曲げ降伏する試験体では高め の剛性を与えたが、スリットプレートとの降伏耐力がせん断によっ て決まる試験体については、載荷初期から最大耐力に至るまでの履 歴挙動において、実験結果と良い対応を示した。今回用いた試験体 に限定される結論であり、今後さらなる実験結果を蓄積していくこ とで、適用範囲を明らかにする必要がある。

\section{参考文献}

1) 秋山 宏：建築物の耐震極限設計 第 2 版、東京大学出版会、1987 年 2) 秋山 宏, 吳 相勲, 大竹章夫, 福田浩司, 山田 哲: 無補強角形銅管柱 梁接合部のモーメントー回転角関係の一般化，日本建築学会構造系論文集 第 484 号, pp.131-140,1996 年 6 月

3) Amadeo Benavent Climent, Sang-Hoon OH、Hiroshi Akiyama: Ultimate Energy Absorption Capacity of Slit-Type Steel Plates Subjected to Shear Deformations, 日 本建築学会構造系論文集 第 503 号, 1998 年 1 月.

4) 加藤 勉, 秋山 宏: 鋼構造部材の耐力(その 4), 日本建築学会論文報告集, 第 151 号, pp15-20, 1968 年 9 月.

5). 秋山・去，高橋誠：鋼構造剛接骨組の耐震性に及ぼすバウシンガー効果の 影響，日本建築学会構造系論文集 第 418 号,pp.49-57，1990.年 2 月

\section{付録 無補強接合部の復元力特性}

ダイアフラムを省略した無補強接合部については、既報 2)で形 状・荷重条件を主たるパラメーターとした 16 体の試験体の実験結 果から、bi-linear 型の復元力特性となることを明らかにし、復元力 特性を規定する降伏耐力・ 1 次剛性・2 次剛性の実験式を提案した。 しかしこの履歴モデルは、接合部の復元力特性だけでなく梁の復元 力特性までを含んだ片スパン分の復元力特性をモデル化したもので ある。降伏耐力については既報 2)で扱った全ての試験体で梁の全 塑性耐力を下回っていたことから、無補強接合部の降伏耐力と，1対 1 に対応するが、1 次剛性·2 次剛性については柱フランジの面外変 形分を抽出する必要がある。なお、復元力特性の形状については、 既報 2)で用いた試験体の大多数で梁が弾性範囲に留まっていたこ 
とから、無補強接合部の復元力特性も bi-linear 型となると言える。 1 次剛性であるが、既報 2)のモデルは直列に慗がった無補強接合 部の剛性と梁の剛性を合成したものであることから、梁の弾性剛性 (計算値)を分離することで無補強接合部のみの剛性を抽出しモデル 化する。既報 2)のモデルを参考に、試行錯誤により求めた柱と梁 の幅の比 $\left(B_{b} / b_{c}\right)$ 、梁の形状比 $\left(h_{d} / B_{b}\right)$ 、柱の幅厚比 $\left(b d t_{c}\right)$ からなるパ ラメーターE $E \Gamma^{*}\left(B_{b} / b_{c}\right)^{4}\left(h_{d} B_{b}\right)^{2}\left(b_{d} t_{c}\right)$ と、無補強接合部の 1 次剖性 ${ }^{c} K_{l}$ の関係を付図-1に示す。両者の間には、式(付.1)の線形関係がほぼ 成り立っていることがわかる。

$$
{ }_{c} K_{l}=25 E \Gamma^{*}\left(B_{b} / b_{c}\right)^{\wedge}\left(h_{d} / B_{b}\right)^{2}\left(b_{d} / t_{c}\right)
$$

一方 2 次剛性であるが、既報 2)で扱った 16 体の試験体のうち、 接合部位置に発生した最大モーメントが梁の全塑性モーメントを上 回ったものが 2 体であった。これら 2 体のデーターを取り除き、1 次剛性と同様に梁の弾性剛性(計算值)を分離することで無補強接合 部のみの剛性を抽出し、既報 2)のモデルの倸数を修正することで、 柱に軸力が作用しない場合の無補強接合部の 2 次剛性 ${ }^{\circ} K_{2}$ をえる 実験式(付.2)を得た。2 次剛性 ${ }^{c} K_{2}$ と式(付.2)のパラメーター $E \Gamma^{*}\left(B_{b} / b_{c}\right)^{3.6}\left(h_{d} B_{b}\right)^{2.2}\left(b_{d} / t_{c}\right)^{2}$ の関係を付図-2に示す。

$$
{ }_{c} K_{2}=0.09 E I^{*}\left(B_{b} d b_{c}\right)^{3.6}\left(h_{d} / B_{b}\right)^{2.2}\left(b_{d} t_{c}\right)^{2}
$$

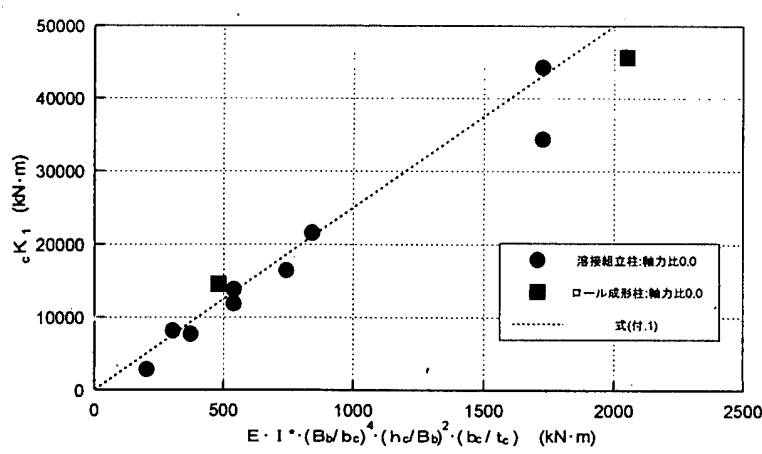

付図-1 無補強接合部の 1 次剛性

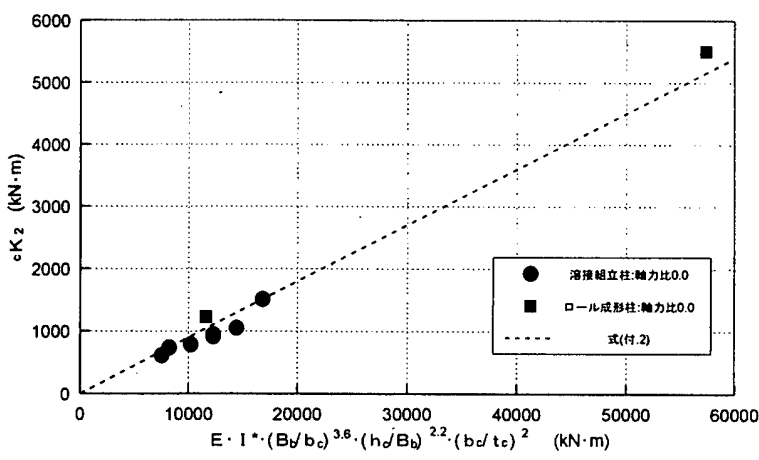

付図-2 無補強接合部の2次剛性（柱の軸カ0) 